case of oxygen; there are, however, two other agencies which also come into play, and tend to diminish the illuminating power ; these arefirstly, dilution of the gas with the inert nitrogen (this factor is wholly absent in the case of the oxygen above); and secondly, more rapid oxidation of the illuminating material. 'The two latter factors produce, however, an effect greater than the first, so that, on the whole, the illuminating power is reduced, although until the air is present to the extent of about 50 per cent., the intrinsic luminosity remnins unaffected, but as the proportion of air increases beyond that, its prejudicial effect appronches that of nitrogen, which it erjuals at the point of complete disillumination. It lins, morcover, been experimentally shown that the reduction in the temperature of the flamo by dilution with atmosplieric air, gradually approaches that which is caused by dilution with nitrogen.

Of what practical value to the gas manufncturer are the experimental facts and theoretical consideritions which have been discussed above?

In the first place, we see that neither is the proportion of heavy hydrocarbons in conl-gas, nor the equivalent in ethylene of these hydrocarbons, a definite measure of the illuminating power of the gns. For the same amount of light may be yielded by a small proportion of $n$ heavy hydrocarbon, like benzene, as is yiulded by a proportion of a lighter hydrocarbon, equivalent to more etlyyene than the benzene. 'Thus the London gas of the Gas Light and Coke Comprany, with its henvy hydrocarbons, equiralent to between six and seven per cent. of ethylene gives as much light as the same gas with these lydrocarbons exchanged for 13 per cent. of ethylene. Thus ly increasing the density of the hydrocarbons, the same light can be obtained by means of $\boldsymbol{B}$ much smaller proportion of hydrocarbons, so thint if the heary hydrocarbons present in any given gas (which, as the amalyses show, are nenrly wholly olefines), conld be converted into liydrocarbons of the acetylene and benzene series, tho illuminating power of that gas would be greatly increased, without importing into it any foreign illuminating constituents. Unfortunately we are at present still very much in the clark as to tho precise conditions of temperature, etc., influencing the conversion of hydrocarbons from one series to another.

In the second place, as to the combustible diluents with which the hydrocarbons are mixed, it is obvious from my experiments that marsh-gas is the one most fitted for developing the illumisuting power ; and, indeed, when an Argand burner is used, it cannot be regarded as a diluent only, but must be classed witl the illuminating constituents of the gas. It must, however, be remembered that marsh-gas also possesses disadvantages as a diluent, for it consumes four times as much oxyren as does the same volume of hycliogen, and produces three times as much hent, besides producing its own volume of $\mathrm{CO}_{2}$, so that it tencls to vitiate tho atmosphere of the room in which the gas is burnt. From my experiments, it also nppears that hydrogen is a more advantageous diluent than carbonic oxide.

Lastly, as regards tho incombustible dilnents which are present in gas, it appenrs thant these should ho conspicuous by theip alsence ; for althongh oxyen itself increnses the illuminnting yower, yet in gns it is alwnys present, with an excess of nitrogen over and above that reyuired for the proportion in atmosplieric nir, so that its presence can only bo ace(t)in. janied by loss of light. Of the incombustiblo diluenty, curbonic nuhydride is tho ono which is most, and atmosplieric nit leust prejuclicial to the illuminating power, whilst water-vapour and nitrogen are intermediate in their action. Carbonic anliydride is now fortunately almost banished from the gas supplied to many of our large towns, whilst nitrogen is allowed to exist, sometimes in no small proportion.

\section{SOME NEW PHASES IN PHOTOMETRICAL PRACIIICE.}

$3 Y$ w. J. DInDIS, F.I.C., F.c.S., CheMIST TO AND SUPEINTENDENT OF THE GAS AND GAS METER TESTING DEI'A ITINEST OF THE METLOPOLITAN BOARD or works.

Tny attention which has been paid within the last few years to the inproved illuminntion of open spaces and large areas generally, and the introduction of the electric light, and cas burners of high power, has inevitably led to a reconsideration of the methods in use for estimating the valuc of the various systems adopted.

It was formerly considered suflicient to estimate the intensity of the luminous rnys in a horizontal clirection only, irresjective of the value of those rays which are actunlly utilized in practicc. Such a system was duubtless useful in those cases in which burners of similar primary construction were employed; but with the various forms of burners and lanterns recently introduced to tho public, such a system is entirely erroncous, and can only afford results of a misleading character.

In order to ascertain the true value of a luminous agent, it is necessary to determine the power of thosc rays falling at angles, varying from the liorizontal to the vertical, or more strictly, through the whole of the semicircle, from the vertical line above to the vertical line below the point of illumination, thus-

For this pulpose the ordinary form of photometer is altogether unsuitable, and can only be employed after" considerable modification, and with an expenditure of time and labour, which is all but out of the question. I lave therefore devised an instrument of entirely different construction to the usual form, which renders the testing of the angular rays both ensy and rapid.

liefore proceeding to the description of this photometer, it will be advisable to discuss the principles adopted, and the reasons for them.

When the Committee of the Gas Section of the International Gas and Electric Exhibition, held at the Crystal Palace last ycar, invited 1'rof. William Foster and myself to report ujon the various buner's exhibited, one of the first joints considered hy us, at the repuest of the committee, was tho estimation of the angular ray's emitted from the various burner's subnitted to our examination. For this purpose we employed a small portable photometer designed by MIr. F. IV. Hartley, and termed lyy him the "Univer:sal" pliotometer. The instrument consists of a liglat narrow table, 11 inches wide, 2 feet $;$ inclies high, and 5 fect 6 inches in length. 'llie senle is divided into inches and tent lis, and is 21 inches in lengtl.. It is fitted into, nud counble of being slifited aml fixed at any position within $n$ groove in the table top, which has a long slot nlong its centre, butow which slot is n lirnss socket connected ly wire cords prassing over pulleys to the winch liandle, similar to the arrangement in the Evans photumeter lor moving the candles, and serving the same puryose, viz. tho movement of tho stumlind. 'The disc corrier' is stupenterl on a stand, the base of which is fittel with $n$ pointer or index coinciling with tho vertical line of the disc. I'ho 
disc carrier, like the scale, may be shifted along the table, and both nust be shifted at the same time, the index of the disc carrier and the zero of the scale always being made to coincide with each other. With the photometer a strong sliding pillar is provided, whicl, like the photometer, stands upon the floor, and is provided with levelling screws and plumb. lines. This pillar serves to carry gas burners, or lamps of various size, as required. The apparatus, ready for use, is shewn in the following woodcut.

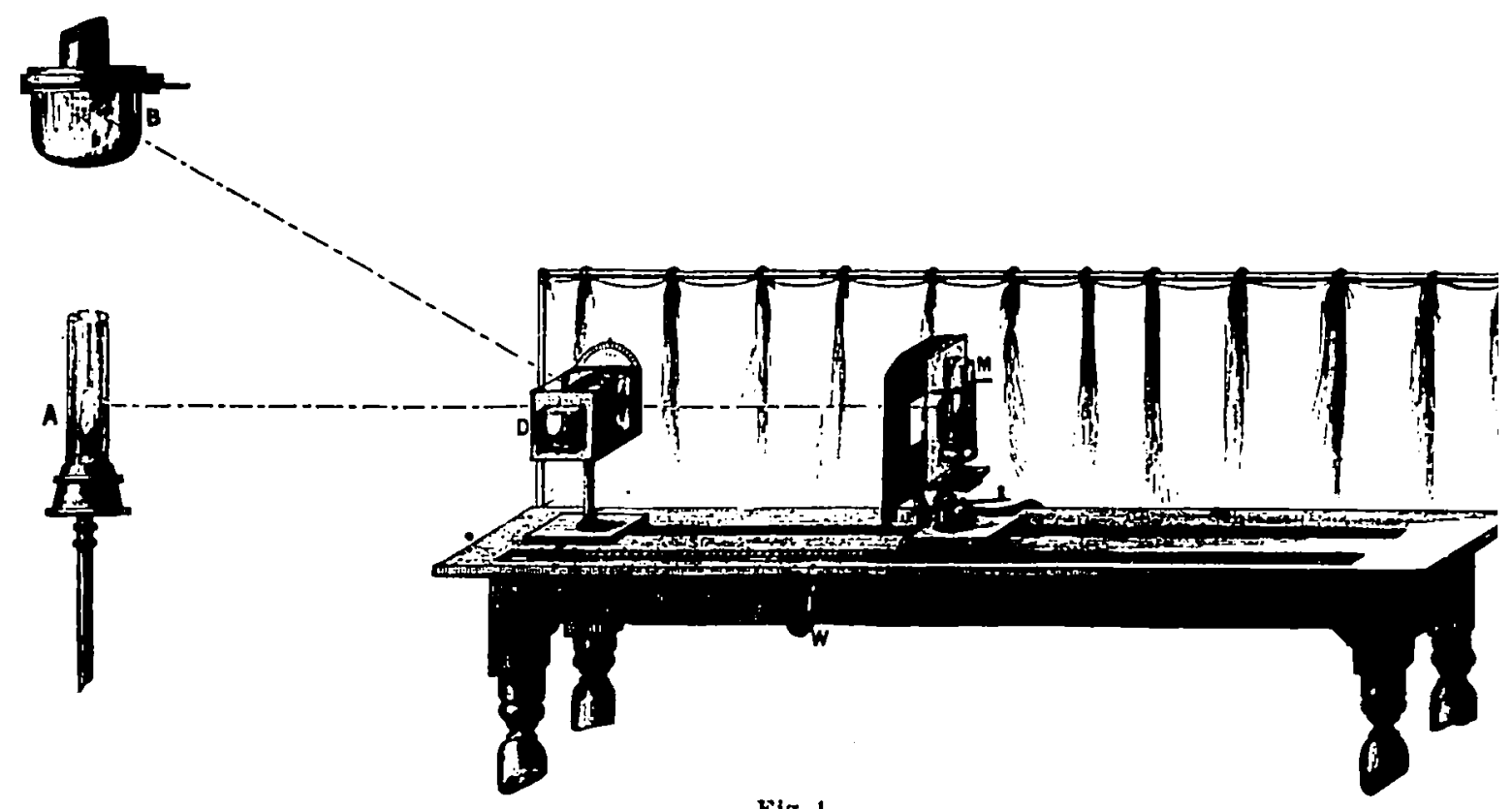

Fig. 1.

Mr. Hartley has calculated a series of tables for use cumference of a circle, whose centre is coincident with with the instrument, by menns of which results are readily obtained.

As submitted to us, the dise was rigidly fixed in the usual vertical position, but at oul request this in was so arranged as to bo susceptible of adjustment at any required angle, so that the lays from the standard and the burner under examination, whatover its position, might impinge upon the screen at cqual angles. The following considerations will shew our reasons for this :-

the centre of the dise, the number of rays impinging upon the unit area of the disc must be less, and continue to decrease, as the position of the light is increased from that of the horizontal line; and this decrease is in exact ratio to tho cosine of the angle formed by tho position of the light with regard to the disc and the path of horizontal rays. 'Therefore the number of rays impinging upon the vertical clise will diminish with the cosine of the angle thus fosmed 'The following diagram shews this very clearly.

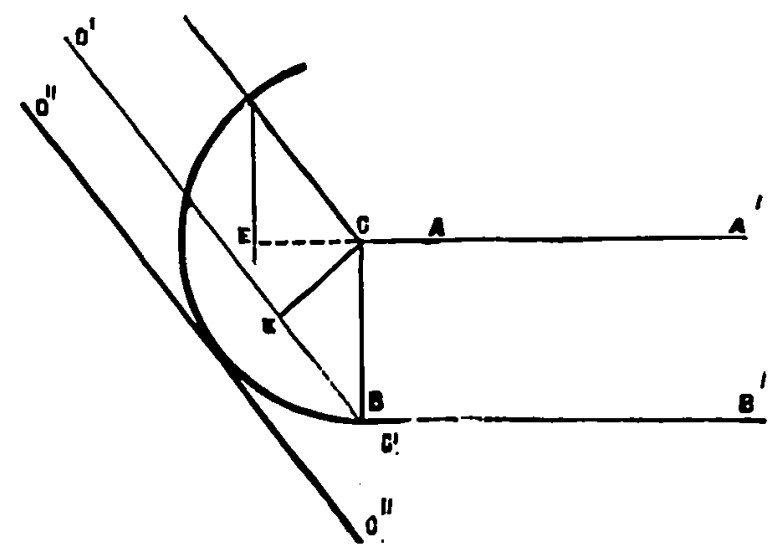

Fis. 2.

When two lights are opposed to encl other in a Let $A \Lambda^{1} \mathrm{BB}^{2}$ represont tho section of horizontal rays horizontal diroction, and a verticnl screen is placed between them, it is evident that the rays implinging thereon must do so in accordanco with tho wollknown law of tho squmres of tho distunce. If the actual distance of ono of the lights from tho screen remains constant while travelling through the cir.

impinging at right angles upon tho vertical disc CCi, and $C D C^{1} D^{12}$ tho section of an erjual number of rays thrown at a downward angle from $n$ source of light placed abovo the horizontal. It is ovident that tho whole of the angular says do not inpinge upon tho disc CC.! but that the ray's which do so aro dofined 
by CDC1D1. By drawing the circumference of $a$ circle whose radius is $\mathrm{CC}^{1}$, and finding the cosine $\mathrm{CE}$, it is at once seen that the section of the rays $C F$, which impinge upon the disc, is in exact proportion to the cosine of the angle of incidence CE.

When the light is raised throughout a quadrant, the number of rays impinging upon the vertical disc will be nil, and thus, nlthough the burner may be one of high illuminating power, such a system of photometry would fail to record any value for it.

Another important point in connection with the vertical disc must not be overlooked, and that is, that when the rays of light impinge upon a surface at an obligue angle, a considerable loss of light occurs by reason of the increase of reflection and absorption, which preponderates over the loss incurred when the angle of incidence forms a right angle. 'This loss increnses with the incrense of the angle, and seriously vitintes any results obtained.

'Iable I shews the results of some tests made in this mannel.

'lust: shewing the Illuminating Power of Angular Rays when tested with the Photometer Disc fixed in a vertical position, and when it is arranged so that the angles of incidence aro identical:-

HAY FHOM HUHNE $225^{\circ}$ WITI HORHONT.M LISE.

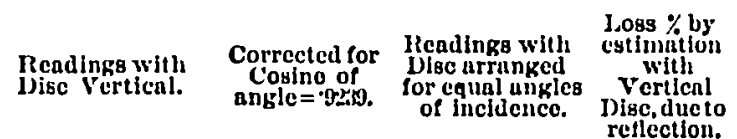

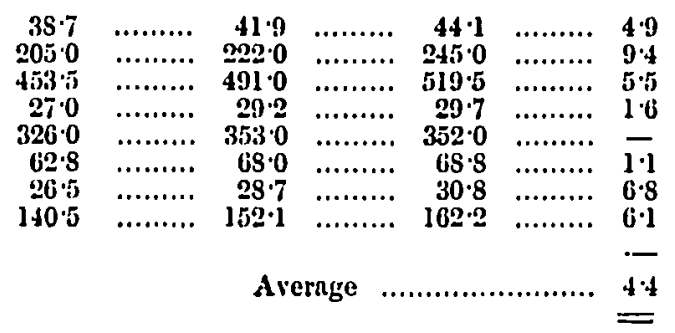

HAYS FRON BLRNEHS $45^{\circ}$ WITH HOMZON'AL LINE. COSINE $=\cdot 7071$.

\begin{tabular}{|c|c|c|c|c|c|c|c|}
\hline \multicolumn{2}{|c|}{$\begin{array}{l}\text { Rendilyge witl } \\
\text { Blsc Verticul. }\end{array}$} & \multicolumn{2}{|c|}{$\begin{array}{l}\text { Correcled for } \\
\text { Cogino of } \\
\text { anglu = } 9239 \text {. }\end{array}$} & \multicolumn{2}{|c|}{$\begin{array}{l}\text { Rendings with } \\
\text { loise urrauged } \\
\text { for equal uwgles } \\
\text { of discidence. }\end{array}$} & \multicolumn{2}{|c|}{$\begin{array}{l}\text { Loss\%by } \\
\text { catimition } \\
\text { with } \\
\text { vertical } \\
\text { Disc, due to } \\
\text { redlection. }\end{array}$} \\
\hline $20 \cdot 2$ & & $28 \cdot 0$ & & $34 \cdot 9$ & & & $18 \cdot 0$ \\
\hline $282 \cdot \overline{3}$ & & 400.0 & & $491 \cdot 5$ & & & $18 \cdot 6$ \\
\hline $20 \cdot 6$ & ... & $29 \cdot 2$ & & $34 \div 2$ & & & 146 \\
\hline $47 \cdot 5$ & ......... & $67 \cdot 2$ & & $87 \cdot 3$ & & & $22 \cdot 0$ \\
\hline $23 \cdot 7$ & [......... & 3310 & $\ldots \ldots$ & $38 \cdot 4$ & .... & $\ldots$ & $12 \cdot 5$ \\
\hline $49 \cdot 4$ & ........... & $70 \cdot 0$ & .......... & $85 \cdot 8$ & .... & $\ldots$ & 18.4 \\
\hline $42 \cdot i$ & .......... & 60.2 & $\ldots .$. & $67 \cdot 1$ & & & $10 \cdot 3$ \\
\hline $15 \cdot 6$ & (.......... & $2 \cdot 1$ & & $25 \cdot 2$ & & & $12 \cdot 3$ \\
\hline 81.0 & & 1148 & & $136 \cdot 5$ & & & $15 \cdot 0$ \\
\hline $124 \cdot 1$ & .......... & 1760 & & $186 \cdot 9$ & & & $15 \cdot 8$ \\
\hline 1042 & .......... & $147 \cdot 8$ & & $101 \cdot()$ & & & $8 \cdot 7$ \\
\hline $15 \cdot 7$ & & $22 \cdot 2$ & & $25 \cdot 1$ & & & $11 \cdot 6$ \\
\hline $88^{\prime \prime}$ & & 1250 & & $14 \cdot 4 \cdot 0$ & & ....... & $13 \cdot 2$ \\
\hline $14 \cdot 5$ & & $25 \div 5$ & & $25 \cdot 7$ & & .... & 0.5 \\
\hline$(j \cdot 2$ & & $13 \cdot 0$ & & $12 \cdot 7$ & & & - \\
\hline $12(1): 3$ & & 18.30 & & $207 \cdot 0$ & & & $11 \cdot 0$ \\
\hline $8 \cdot 0$ & .......... & $12 \cdot 7$ & n...... & $12 \cdot 0$ & & & - \\
\hline $52 \cdot 2$ & n........, & 740 & on.... & $86 \cdot 5$ & & ........ & 145 \\
\hline
\end{tabular}

RAYS FROM DURNER $67 \cdot 5^{\circ}$ WITH HORIZONTAL LINE. COSINE $=3827$.

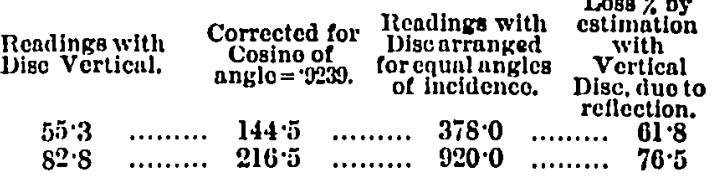

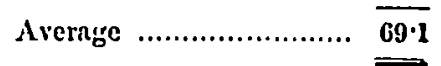

After correction for the diminislucd number of rays impinging upon the disc at the different angles, the value obtained is deducted from that found by estimation with tho disc arranged for equal angles of incidence, and the difference between the two results calculated into percentages. By this means I find that when the burner is at an angle of $22.5^{\circ}$ above the borizontal, the average loss due to reflection from the vertical disc is 4.4 per cent. ; at $45^{\circ}$ it is 12 per cent. ; and at 67.5060 yer cent.

It is obvious, therefore, that the method of estimating the illuminating power of angular rays by menus of a vertical clisc is erroneous.

By arranging the disc so that the angle of incidence is cequal on either side, thus--

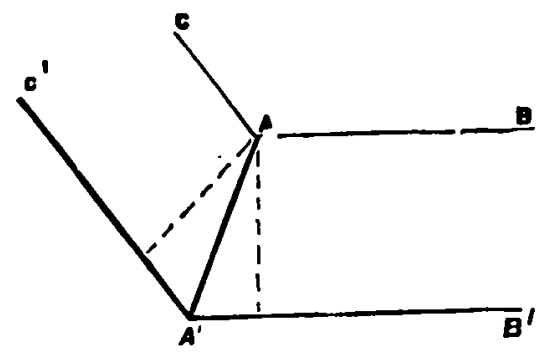

Fig. 3.

Disc $A A^{\prime}$. Ilorizontal rays $A B A^{\prime} B^{\prime}$. Angular rays $\mathrm{C} \Lambda \mathrm{C}: \Lambda^{\prime}$

we equalise both the proportionate number of rays inpinging thercon, as well as the loss due to reflection. Determinations thus made possess nll tho vulue of those made with a vertical disc and horizontal rays on either side in tho usual mnnner.

For the purpose of comprison with the " hadial" photometer, as I havo termed my design, I nppend the following woodcut of a portable phutometer, mado by Messrs. Sugg it Co., which embraces all tho essentiul points of the most approved puttern of the ordinary bar photometer. It is easily taken to pieces and packed in a box for conveyanco and is readily fitted uj for use, witl a little practice, in five minutes.

'The principlo involved in tho constriction of the Radial phutometer is very simple, viz.. : that tho light under examinntion should bo rigidly fixed in one position while the estimations of the valuo of the angulur rays emitted from tho horizuntal to tho vertical, cither ubovo or below, aro boing made, thus onsuring perfect stendiness of the burner, ol other luminous point.

'Lie aljumatus consists of two verticul supports, ono of which is permanently fixed to tho base-boned or foot, while the one on the right hand travels on rollers on the base-board in such a position that it will run in front of the fixed support. 
The two uprights are connected by a bar, the ends of which work upon trumnions, or axles, attached to blocks which travel in the grooves of the uprights. These blocks can be clamper in nny desired position. One end of the bar is attached to the front of the fixed upright, while the other end is attached to the travelling upright at the back, so that when the two upriglits are in juxta-position the bar is perpendiculnr between thent. 'The centres of the trunnions correspond in position with the centres of the two gradunted dial plates in front of the uprights. The distance between the centres of these dinl plates is 50 inches. It is therefore evident that whatever position the bar may be in, the distance from the centre of one dial to that of the other must be constant. In front of the clial plate on the travelling upright the screen or disc-holder is fixed, so that its centre is coincident with the centre of the clial.

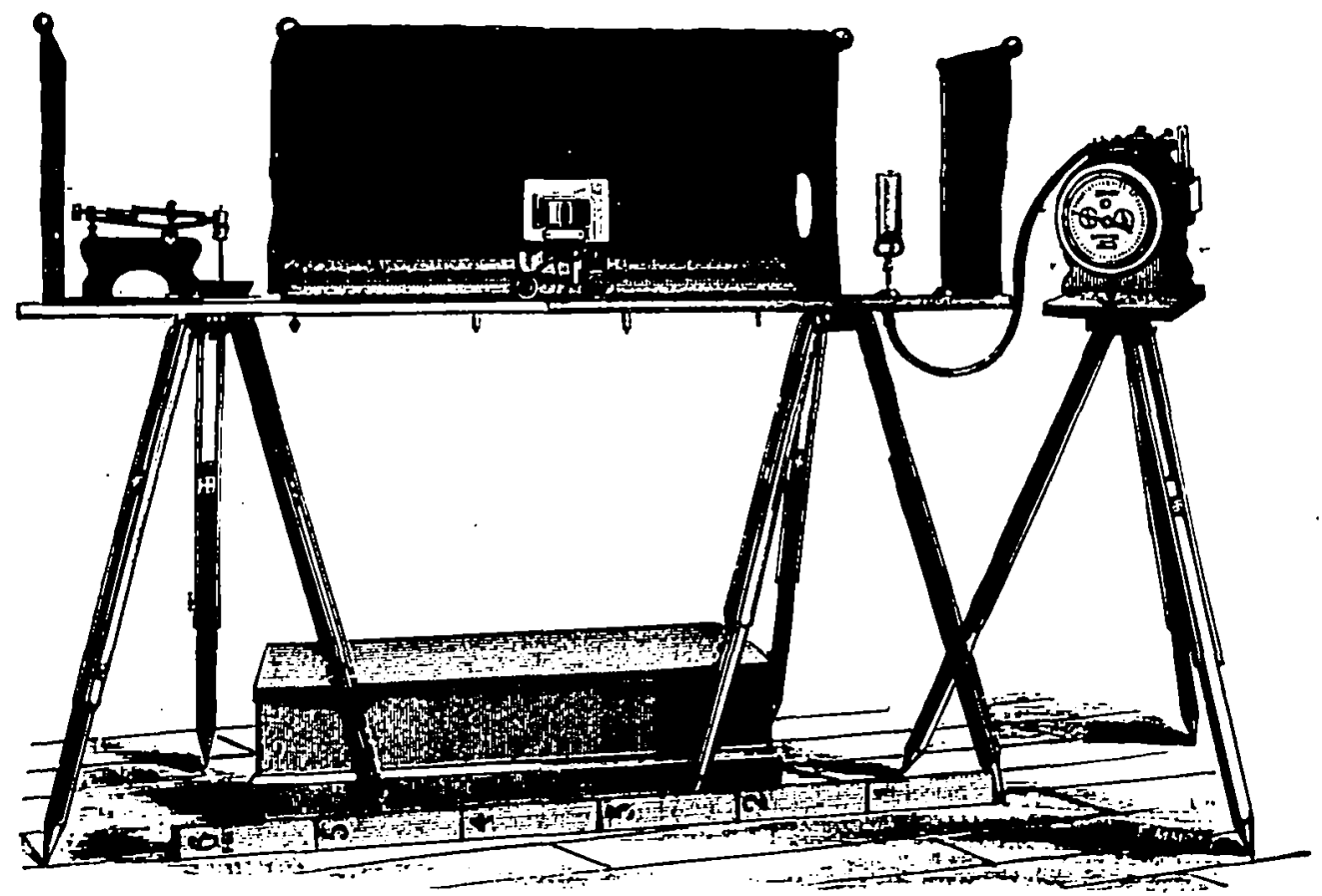

Fig. I.

Attached to tho block in the groove of the travel- extent which can be attained by the dise and standard, ling upright support is the horizontal bar carrying the strundard.

The standard is supported in front of the horizontal bar by a travelling carriage, working on rollers, and is moved by a cord and winch, conveniently plnced on the right-hand sicle of the graduated dial on tho support. Attached to the block carrving the photometer disc is a brass rod, which is brought well forward and then curved round for the purpose of carrying a velvet curtain to screen off extrancous light when readings are being taken.

The two dial plates are graduated; the larger one on the fixed support in degrees, and the smaller one on the travelling support in lialf degrees, which are numbered as whole degrees for the purpose of facilitating the setting of the disc for ecjunl angles of incidence, so that when the bar is set, siny, at 10 degrees, the disc-pointer is to bo set at 40 , it will then be in the proper position, viz., 20 degrees. 'The disc may be arraned to work nutomatically with the movement of the bar by means of a simple mechnnical appliance, so that whatever may be the position of the bar, the disc will be at the correct angle.

A brass rod is provided for adjusting the position of the burner, fec, to be tested. It has to be pushed through the centre of tho block and trumnion on tho fixed upright support, and will then be at right nngles with the plane of the dial, and project exnctly through its centre, by which means it is teasy to fix tho exret position of tho llame in front of the apparntus. 'Tho light to be tested may bo brought forward to the full which, olsviously, can be regulated as desired, so that the size of the burner or lentern-which may be tested with this apparatus-is practically unlimited, due regard being paid to the length of the bar and the power of the light.

When a test is commeneed the light to be examined is fixed on the support attaclied to the block in the fixed upright, and nccurntely centred with the dinl plate, which is to be lowered to the bottom of the groove in the supjort. 'Tluo block in the travelling silpport Jas next to be raised, which operation will bring it immediately over the burner, the travelling upright being in front of the fixed support, and the pointer on the bar indicating $90^{\circ}$ on the lurge dial plate. 'The pliotometer disc is to be arranged for ergual angles of incidence, by turning it until its pointer is at 90, when a reading can bo taken. 'The clamp holding the top lolock in prosition is then loosened, and the handle working the rack and pinion of the travelling slipport turned until the har is at an angle of $80^{\circ}$, the block must then bo clamped, the dise adjusted to $80^{\circ}$, and so on for cach degree or ten degrees as desired, until tho horizontal rnys ne estimated. 'Tho block supporting the light is then to bo raised to tho higher position, and tho bar adjusted for tho desired angle below the horizontal, and a second series of readings tnken until tlio dowuward vertical rays are estimaterl.

'Tho following wood-cut shows tho instrument arranged for testing tho l'nys thrown downward at an angle of $40^{\circ}$ 
The Bunson, or greased disc, under ordinary circumstances, with liphts of equal colour, is all that can be desired; but when used for testing the electric light or gas burners of the recuperative class, it is very unsntisfactory, nnil at times useless, in consequence of the grent difference in tint between the light emitted from the standard and that of the burner under examination. I have, therefore, abandoned its use for these jurlposes, and use a modified form of the Jeeson or "Star" disc. As originally designed, this disc was unsatisfactory, in conserpuence of the "cockling" of the two this papers on either side of the prerfornted stout paper. To such an extent was this fault found to interfere with the rendings, that the Gas Referees, some limo back, disallowed its use at the Metropolitan gas testing stations under their charge.
Finding that the Bunsen disc did not answer all the purposes required, I modified the Star disc by pressing togethel the three papers, of which it is formed, with very thin starch water, and drying the moist dise under pressure. This trentment effectually jrevented"cockling" and the use of the dise in its present form is sanctioned by the Gas Referees.

The great advantage of this form of disc is that very sharp readings are rendily obtained, with totally diflerent coloured lights ; red and blue lights are contpared with the greatest ease, an advantage which no words of mine can enliance.

It is to be hoped that in future all comparative tests of the value of various burners will be so conducted as to shew the actunl work dono by them, not only in one direction, but in all directions. With argand and other circular burners, this can be done

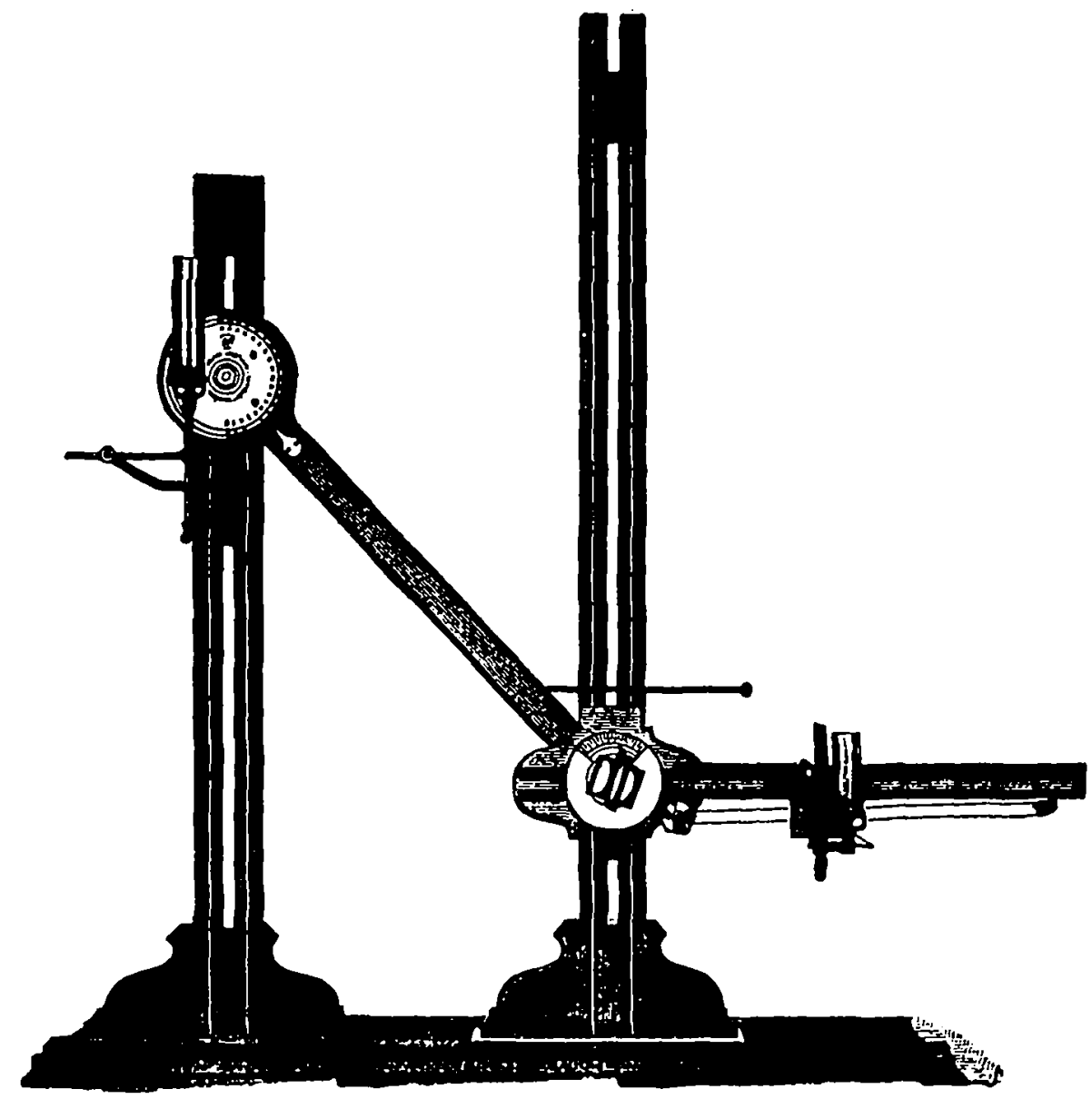

Fig. 5.

by making one series of tests from the vertical nbove to the vertical below, nt every 10 degrees. But in the case of flat-flame burmers, it is necessary that this series should be made in dupliente, one with the flame flat, or at right angles to thio bnr of tho photometer, and ono with tho Hamo plineed with its elgo to tho bar. An oxtensive series of experiments on this point has shown that very considerablo dilioronecs exist between tho quantity of light omittel from the lint surfaco and from tho edgo of various burners; this difforence varying from 10 to 35 per cont. of tho light omitted from the that surfuco. Thoroforo, it is very necessary that tho two series of tests should bo mado and nn ayerage taken, which should be held to represent tho value of tho burner.

For tho purpose of facilitating comparison, I havo drawn tho following diagrams, representing tho quantity of light emitted in tho different directions, by which it will bo seen that the ordinary method of testing burnors does not givo really comparativo rosults of any value, as tho horizontal rays in encl caso aro curiously less in illuminating power than the angular ones, both above and bolow them ; therefore Jorizontal testing only is unfnir to the burner, and in nll compotitivo,trials should to supplomonted in tho mannor I have described: 


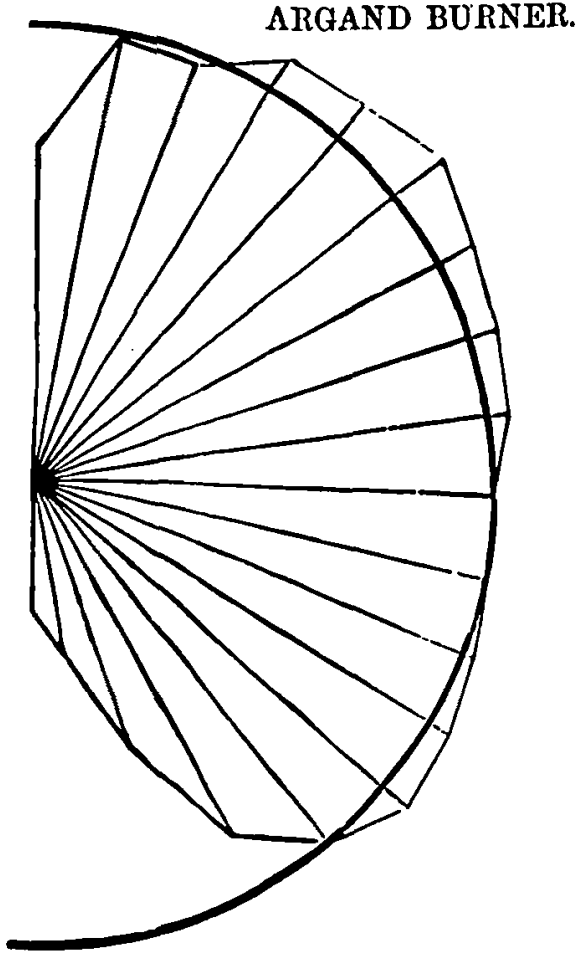

The thick line represents the circumference of $n$ circlo whoso radius equals the value of the light thrown from the burner
horizontally.
I am aware that I an proposing a complete revolution in practical photometry, but, having shewn a full justification for it, I venture to hope that those experieneed will readily ayree with me, that the sooner the old erroncous methods ale abandoned the better.

By means of the radial photometer, and tho improved Leeson's disc any light can be readily tested in a most satisfactory manner, and results obtained which will fully repny the small amount of additional work expended in their production.

The importance of a reliable standard of light is admitted by all cxperts in plotometry, and a great deal of work has been dono by various investigators with the view of obtaining something of a more definite character than candles. It is to be hoped that before long a change from the present parliamentary standard will be unthurised, and one or more of tho proposed substitutes for candles made legal.

Enough has been done to prove that the Pentane test of Professor A. Vernon Harcourt, and the scrcen of Mr. Methuen possess all the requirements of practicul stumdards ; and where expenso is no object in the ono case, or gascous fuel is obtainable in the other, and a small degree of illumination is desirable, little objection can be made to them. 13nt where gnseous fucl is not at hand, and when a standard of light of bigher illuminating power is desired, no better stundard can be advised than the sperin oil lamp of the late Mr. 'I. W. Keates, which was fully described by him in the Joumal of Ges Lighlung of March 16,1869 . At that time the lamp was arranged to give a light equal to 10 candles, but since then it has been improved so as to yield a light equal to 10 candles, which can be modified, when clesired, to givo a light of two, five, or ten candles, by simply cuting ofl

FLAT FLAME BURNER No. 1.
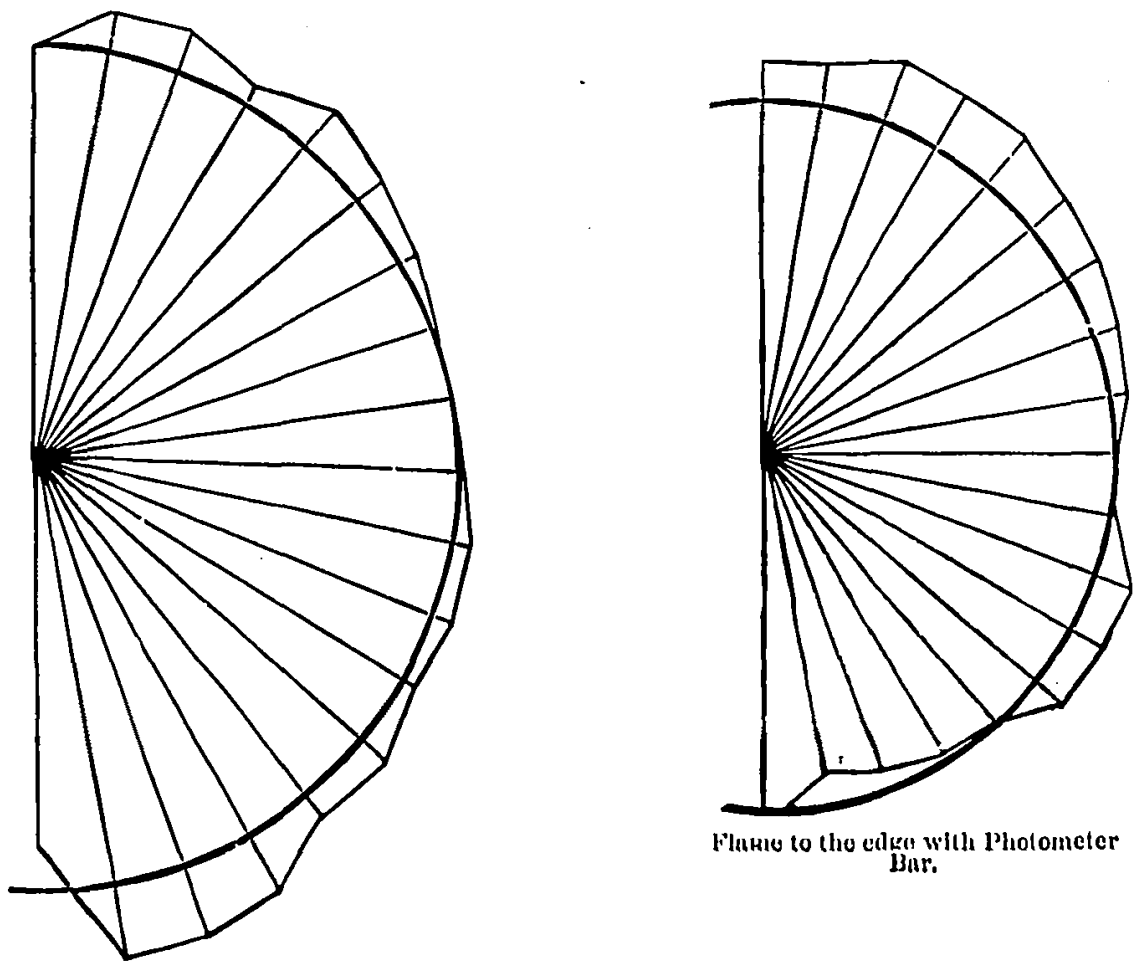

Flingu to tho edlet will pholometer Bur.

Flamo at right angles to Photometer Bar. 


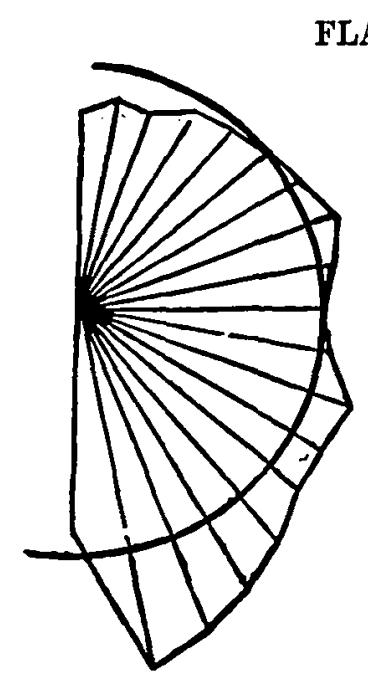

Flame at right angles to

Photomoter Lar.

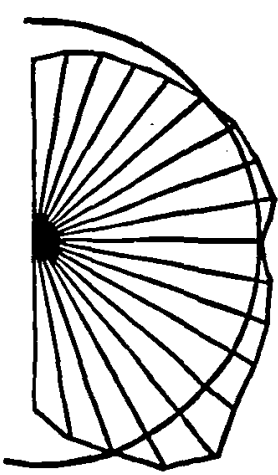

Flame with the cdgo to Photometer Bar.

portiony of the flame by means of $n$ suitable screen; of the fact that, when properly used, the lamp yields in which case sufficiently nccurate results for orcli- a light which is practicnlly constant. In proof of this nary purposes can bo obtained without weighing the statoment, I would puint to tho following series of oil. tests of a gas flame arranged to yield a steidy columm

In raising this question of the lamp, I am perfectly ! of light, 3 inches in lieiglit, by cutting of the light aware that many will think that I am "thmshing a from tho top of the flame with a sereen, so as to dead horse." In answer to those who do so, I will exclude errors, as far as possible, arising from ask for any systemntic tests mnde with this lamp slight rarintion of consumption or quality of the which shall prove its umrelinbility. 'The objection ' gas.

that the lamp is used with a wick I hold to be utterly 'Inble II. shews the results of some preliminary unscientific and unworthy of consideration in the face tests made in this manner.

\section{TABLE II.}

Shetuing the results of tests of the angular rays emitted from an argand, and from two flat flame burners of different construction. The photometer disc was arranged so that the angle of incidence wets equal on either side. Results stated in percentages of muximum intensity.

\begin{tabular}{|c|c|c|c|c|c|c|c|c|}
\hline \multirow{2}{*}{\multicolumn{4}{|c|}{ Raje from Burnor. }} & \multirow[b]{2}{*}{ Argand. } & \multicolumn{2}{|c|}{ Flat Flanic. No. 1.} & \multicolumn{2}{|c|}{ Flat Flamo, No. 2.} \\
\hline & & & & & $\begin{array}{c}\text { Elamo at alght } \\
\text { ungles to } \\
\text { Photomoter } \\
\text { llar. }\end{array}$ & $\begin{array}{l}\text { Flamo with } \\
\text { the edgo to } \\
\text { Photolinotor } \\
\text { Bnr. }\end{array}$ & $\begin{array}{c}\text { Flameat right } \\
\text { angles to } \\
\text { Pliotonetor } \\
\text { Bar. }\end{array}$ & $\begin{array}{l}\text { Flumo with } \\
\text { tho edfo to } \\
\text { Photomotor } \\
\text { Bur. }\end{array}$ \\
\hline $\begin{array}{l}90^{\circ} \mathrm{a} \\
80^{\circ} \\
70^{\circ} \\
60^{\circ} \\
50^{\circ} \\
40^{\circ} \\
30^{\circ} \\
20^{\circ} \\
10^{\circ} \\
10^{\circ} \\
20^{\circ} \\
30^{\circ} \\
40^{\circ} \\
50^{\circ} \\
60^{\circ} \\
70^{\circ} \\
80^{\circ} \\
80^{\circ}\end{array}$ & $\begin{array}{l}\text { " } \\
\text { " } \\
\text { " } \\
\text { " } \\
\text { " } \\
\text { " }\end{array}$ & $\begin{array}{l}\text { " } \\
\text { " } \\
" 1 \\
" 1 \\
" 1\end{array}$ & 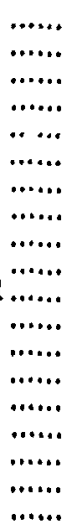 & $\begin{array}{r}64 \cdot 2 \\
04 \cdot 3 \\
86 \cdot 4 \\
06 \cdot 5 \\
97 \cdot 1 \\
100 \cdot 0 \\
97 \cdot 1 \\
90 \cdot 5 \\
95 \cdot 0 \\
90 \cdot 0 \\
90 \cdot 0 \\
02.0 \\
04 \cdot 3 \\
97 \cdot 1 \\
01 \cdot 5 \\
81 \cdot 5 \\
57 \cdot 2 \\
36 \cdot 5 \\
20.4\end{array}$ & $\begin{array}{c}84 \cdot 8 \\
94 \cdot 2 \\
05 \cdot 0 \\
92 \cdot 7 \\
95 \cdot 6 \\
91 \cdot 3 \\
87 \cdot 0 \\
84 \cdot 0 \\
84 \cdot 0 \\
84 \cdot 8 \\
89 \cdot 1 \\
89 \cdot 1 \\
87 \cdot 6 \\
04 \cdot 2 \\
93 \cdot 5 \\
98 \cdot 5 \\
100 \cdot 0 \\
09 \cdot 2 \\
74 \cdot 0\end{array}$ & $\begin{array}{l}79 \cdot 6 \\
79 \cdot 6 \\
84 \cdot 0 \\
8 \cdot 4 \cdot 0 \\
83 \cdot 2 \\
79 \cdot 6 \\
70 \cdot 8 \\
75 \cdot 3 \\
74 \cdot 0 \\
71 \cdot 0 \\
71 \cdot 6 \\
76 \cdot 8 \\
76 \cdot 8 \\
70 \cdot 0 \\
69 \cdot 5 \\
68 \cdot 1 \\
60 \cdot 7 \\
63 \cdot 8 \\
72 \cdot 1\end{array}$ & $\begin{array}{r}50 \cdot 0 \\
60 \cdot 0 \\
60 \cdot 0 \\
64 \cdot 0 \\
66 \cdot 0 \\
68 \cdot 0 \\
72 \cdot 0 \\
74 \cdot 0 \\
70 \cdot 0 \\
68 \cdot 0 \\
72 \cdot 0 \\
78 \cdot 0 \\
76 \cdot 0 \\
78 \cdot 0 \\
84 \cdot 0 \\
88 \cdot 0 \\
94 \cdot 0 \\
100 \cdot 0 \\
6 \cdot \cdot 0\end{array}$ & 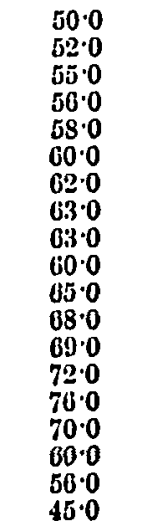 \\
\hline
\end{tabular}


TABLE III.

Shewing the results of tests made with Keates' lamp, of a flome 3 inches in height, the liglht from portions above that height being cut off by means of a screen.

\begin{tabular}{|c|c|c|c|}
\hline \multicolumn{3}{|c|}{$\begin{array}{l}\text { Lipht piven by } \\
\text { Stumdind Lamp, } \\
\text { corrected for consumption } \\
\text { of Sperm. }\end{array}$} & $\begin{array}{l}\text { Ascertained value of } \\
\text { Gas Flame. }\end{array}$ \\
\hline lat lany & 16.55 & ….................. & $18 \cdot 03$ \\
\hline 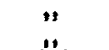 & $\begin{array}{l}16 \cdot 52 \\
10.89\end{array}$ & ........................... & $\begin{array}{l}17.85 \\
18.07\end{array}$ \\
\hline 2nd"day & 15.50 & 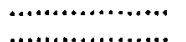 & $\begin{array}{l}18.07 \\
17.99\end{array}$ \\
\hline 11 & $16 \cdot 21$ & 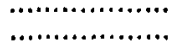 & $17 \cdot 94$ \\
\hline " & $16 \cdot 7.5$ & ................. & $17 \cdot 62$ \\
\hline$"$ & $16 \cdot 38$ & ….................. & $18: 32$ \\
\hline 3rd" ilay & 17.02 & ..................... & 18.21 \\
\hline & 16.45 & (n................ & 15.06 \\
\hline 4th" Iny & $16 \cdot 10$ & 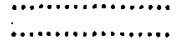 & $\begin{array}{l}15 \cdot 11 \\
1793\end{array}$ \\
\hline$"$ & $16: 50$ & ................. & $15 \cdot 13$ \\
\hline sth" dny & $17 \cdot 08$ & [................, & $17 \cdot 93$ \\
\hline Dedatigy & 17.00 & 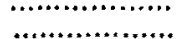 & 17.05 \\
\hline ", & $16 \div 2$ & ............... & $18 \cdot 05$ \\
\hline$" 1$ & $17 \cdot 00$ & . & $15 \cdot 06$ \\
\hline
\end{tabular}

$71 \%$ of the tests were within 0.1 cantle of the menu.

The tests werc made at intervals, nnd on varions days, during which, practically, no varintion was found in the illuminating power of the gas used. 'l'he results may, therefore, be taken as fairly rejresentative of the work done by the lnmp.

The conditions under which the lamp must be burnt, are very simple, viz., clean oil and a clean wick. For particulars regarding the oil I camot lo better than refer to Mr. lieates' pajer above mentioned What he said there holds trite now, and will hold true so long as there are suermi whales to be caught, and a tempernture of $40^{\circ} \mathrm{F}$. outainable.

The only objection of any moment which can be macle to the use of the launl, is that it requires a certain interval of time to elajse between the first lighting and its readiness for use, but as this interval is only about thirty minutes, I do not see that this objection should linve weight with those who are desirous of obtaininir correct results from an operation which requires such an exercise of patience as photometry admittedly does. It is juroverbial that impatient operators make bad pliotometrists.

The great advantages to be derived from a 16-candle standard, which is ready for uso at all times and in all places, are obvious.

In the first instance, tho advantage of using a standarl which approximates more nearly to the power of the light under exinnination, must bo jereeptible to the most superficinl observer, as by this neans the errors due to the multiplication of the readings by 8 , 16, ete., are elimimated, and more correct results obtained.

In the second place, the colour of the standard lamp is almost identical with that of the ordinnry 16 -candle gas flame, and, therefore, readings with. the disc rendered casicr.

In the third place, the use of the 16 -candle lamp cnables estimations to be made of the value of ligh power kas burners and electric lights, with far grenter facility and exactness than enu possibly bo the caso with standards of lower power; with the further advantage of shortening the photometer bar.

I have thus shew'n enongh to point out the clice advantages of the lam]. The oljection that "the lumu will not Lurn," is so utterly at valinnce with all the facts, and the results of hundreds of tests made with it, that I jass it over without further comment.
In conclusion, I may state that I do not claim to have settled the many vexed questions arising in photometric practice. On the contrary, the radial photometer was designed to assist in their investigntion, and it is to be lioped that its systematic use will throw considerable light on many points connected with the construction of gas burner's and other illuminating agents, which at present rest in obscurity. If my endeavours to provide a workable instrument, which shall nssist in their solution, meet with any degree of sucess, I shall be more than satistied.

Discessiox.

The Cunmus said the meeting land to thank Ir. Percy Frankland and Mr. Dibdin for their most interesting pajers on very important subjects. It was very encournging to seo so many representatives of gas manufacturing industry present; because, the oncrntions concerned acted and reacted upon other branches of chemical industry. Reference to the pages of tho Journal would show how that fact was recornised, and how freguently the subject was touclied vpon. One could not help fecliner that ehemistry lial not yet done all it could for the gas industry; and he believed that in tho future they would owe a great deal more to its products, besides fretting the advantages of the light, for the gas industry had not yet arrived at the perfection which it would some day rench. Then it was wonderful to see how the art of photometry had kept pace with the necessities of the chnnging lights of the present time ; and the points to which their attention had been called wero useful, not merely from a pliotometrieal point of view, but also from a practical one. They conld not he!ly thinking that it was exceclingly jrobuble a grood deal of the conplaints of the efliciency and economy of gas-lighting might be owing, in no small degree, to the detestable yunlity of the bumer's used, while at the same time it was no doubt jossible to use a rood burner in such a way as to get a bal result from it. He would, with these preliminary observations, invite remarks from the meeting upon the papers which land been rend.

Mr. F. WF. II Aletsts said that being an old photometrist lie wished to mike a few remarks. Ho believed that he was nmong the first of those who showed the impertance of testing the powers of gas flames at more tlinn one angle; and in the anticles which he furnished to the Journal of Gers Jighting in January, 1881, he described the photometrie arrnngement which he used. 'J'hat arrangement was developed in the "Univer:al," which was before them, which instrument was employed hy Mr. Dibdiu and l'rofessor Foster as stated, after the nirangement for the disc to be set at nuy desired nngle had been made. That modifiention and improvement wis entirely duo to the gentlemen named; and ho hojed that tho system of plncing tho dise at a mid-nugle between the unit light and any other which was opjosed to it, would be universally adopted, as therely' the tino relations in power's ware found. He so used tho photometer in its lnter improved state. In his enrlier experiments he had, however, sought to ascertain the antount of light which would be received on a perpendicular plane, such as a wall, for instance, where tho dise was fixed vertienlly, as it shomlil bo for such furjose, inasmuch as it was elenr thont the walls of a ronu conld not le turned or twisted to accommodnte is light in tha ceiling. 'The nngle-screan motholl was the srientilic one; and Messis Dibdin and Fuster wero entitled to the credit of devising it. 1la was somewhat surprised to henr that when the rays of light fell at un netuto angle on the disc, so large a number wore, as it were, rendered insensiblo to tho oyes of the observer, seoing that tho intensity of 
illumination was judged of from the inages of the disc in mirrors; but he liad no doubt but that Mr. Dibden's statoment was quite correct. As regards flat-flames it was the fact that much less light was delivered from their edges than from their surfaces. He had determined the difference with very many gas and paraftin oil flames. If, however, a curved reflector were placed behind a flat flame the horizontal light would be found to be greatest when the edge of the flame was presented to the photometer disc ; becnuse, for one thing, the wide tlame covered more of the reflector, and prevented it from so fully acting. He regretted that he had not yet worked with Mr. Kentes' linups. That gentleman's lamented denth prevented him obtaining it when he had opportunity to try it, and since, he had been too much occupied to find time. He hoped, however, to be able to fully try it presently; but he must differ from the opinion of Sir. Dilidin that a jowerful standard of light was necessary, his (Mr. Hartley's) persomal experience being that with a unit not cxceeding two-candles jight the eyes were not so distressed and wearied as when the unit light was powerful ; a matter of importance when operations extend over seven or eight hours. With a two-candle unit he had tested lights up to a 10010 candles' yower. During the past four months Mrr. Heisch and himself had been engaged in investigations on photometric light units, but lanps with wicks were, by instructions, exeluded from the inciuiry. MIr. Dibdin had shewn them a novel and very beautifu! instrument, and he hoped that its employment would lead to the development of many interesting and valuable facts in photometry.

Dr. E. FluskLand had been much interested in the pajer which liad been brought before the Society by Mr Dibdin. He was not aware betore how great the difference could be in the light enitted by argand and fish-tail burners in difterent directions. It was quite obvious that photometric reading's of this kind wero absolutely essentinl if anything liko a true result was to be arrived at, and he thought theapparatus which Mr. Dibclin had contrived conld be easily worked, and it was obviously susceptible of the attainment of accurute results. He had not quite understood the remarks of Mr. Hartlay with regard to the reflection from tho pajer, but it unight be well to bear in mind that the reflection of light from a surfuce of paper was very different incleed from the reflection of a metallic sulface; the reflection from pajer increased continually in amount as the angle of incidence formed by tho rays and the pajer diminished, so that at last, when the rays made a very small angle, a very lurge proportion of them in. deed would be reflected; but how far that would aftect the appearance of the dise he was not prepared at the moment to say. Such a jhotometer would bo of essential service in deterujujug the ratio of the illumiuatiog power between the arc lights, which had never yot been properly tested, and ho hoped by tho help of this instrument they would obtain more trustworthy results than hitherto. With regard to his son's paper, and the experiments he had brought hefore the notice of the Society, he had not many lemarks to offer. It was obvious, as had been yointed out, that there was a very marked difference in the proportion of what might be termed oxcess-nitrogen in tho grases of the different periods mentioned, which miglit reyuire some explunation. In his own experiments of 1851 , it would bo seen that the nitrogen was but very slightly in excess of that required by the yuantitics of oxygen which were also prosent, whilst the subseyuent experiments shewed that the proportion of nitrugen to oxygen had been constantly mctensing. He spoke subject to correction by the practical mei who were present, but it occurred to him that tho fol- lowing might be the explanation: In 1851, gas was made almost exclusively in iron retorts, and those retorts were much more gas-tight or air-tight than the earthenware retorts since employed. $\Lambda$ that time, no doubt the exhaustion was carried on much as it was now-he did not know whether the exlaustion was now greater than it was then-but, at that time, the super-exhaustion, though it would not have the effect of drawing air into the retorts themselves, would draw it in through leaky joints and insufficient seals. There would thus be drawn in the proportions of oxygen and nitrogen contained in the atmosphere. But all the air drawn into a leaky retort would be almost instantaneously deprived of its oxyren, so that if there were a leaky retort into which the furnace gases were rlrawn, nitrogen, without tho corresponding proportion of oxygen, would become mixed with the gas. He hoped the results his son had obtained, in ascertaining the hydrogen density of the illuminating hydrocarbons, would eventually lend to a really trustworthy method of determining chemically the illuminating power of gas. As soon as the intrinsic illuminating power of the different illuminating hyclrocarbons, and especially the acetylene, liad been determined, he thought a formula night be devised, which would enable the illuminating lowel of a gascous mixture to be calculated from the carbon of hydrogen densities with grenter accuracy than could be attained by photometric methods. Althoughit was a method which could never, perhaps, be bronght into daily practice, still it would be found very useful to submit gases from time to time to that crucial test. It was not impossible that an aplaratus could be contrived, so that by, sny, a weekly analysis of the gas of a town, the average quality of that gas could bo determined. If a suall holder were made to receive a current of the gas, proportional to the amount being supplied at any monent, and then the contents submitted to a weekly amalysis, probably a fairly good average would be arrived at, provided they could devise a working formula for the determination of the true illuminating power from the chemical composition.

Ilr. David Suga said :- With regard to placing the discs used in photometry in relative positions to receive the light from the standard and that from the light to be tested equally on both sides, he would yuote an instance when his father was engaged making experiments on the Thames Embankment. For this purpose a Richio dise (in the form of an e(puilateral triangle) was employed. The sido towards the stanclard was fixed, the other made movable, so that it could bo elevated into position, making the angles of incidence equal. The images of the discs were received upon a mirror pluced above, and at an angle of $45^{\circ}$. It is curious to note, ins compared with the results obtained by Mr. Dibdin with his radial photometer, that the observations made by Mr. Sugg with the disc firstly in its normal position and then elevated-making the nngles of incidence equal-the realings remained unaltered. This was clue, no doubt, to the fact that tho same beam of light was recoived upon the disc, the only differenco being tho respective angles at which the lights infringed upon it. When short-bar photometers aro employed it may bo found necessary to linve the menns of adjusting the disc.

Mr: W. LANT.Canenten said it had been pointed out very clearly that some of the remarkable results ubtained with regard to the illuminating power of gas, as compared with its chemical composition, were to bo explained by the temperature of the flume resulting from the burning of the $\mathrm{g}^{\mathrm{n}} \mathrm{s}$; and ho would like to ask whether that line of inquiry hind been at all followed out in the direction of investigating tho 
temperature resulting from the combustion of gas of known compositions. 'l'his was an important point, when the constantly incrensing use of gas for heating purposes and in gas engines was considered, and it also bore upon the proposal of the late $\mathrm{Sir}$ WV. Siemens to partially separate the gaseous products of conl distillation into henting gas (tho first and last portions) and lighting gas.

Mr. OTto HeHser, as one who had to spend a considerable part of his time daily in testing and examining gas, wns very glad to hear Mr. Dibclin sny that there was every prospect of the present standard of measuring illummating power being speedily ahandoned. There had been much talk of change for a long time past, but we now apluarently might hope that not mnny months would elapse before it was realised. Candles, in fnet, were not stnudards at all-every gas examiner could not but feel that. Could one feel any conficlence in the accuracy of the results of one's testing if three successive tests of the same gas, on the same eveningr, but with different candles, could indicate 15,16 , and 17 cindle-powers respectively, when, doubtless, the gas itself had remained mactically the same. To did not mean to say that such wirlely discrepant results were the rule, but still they did occur, nud made one feel very diflident in certifying to any slight deficiency in illuminating power of any given gas supply, when one considered that the certificate would probalily form the basis of $n$ prosecution against the Gas Compnny. This alssence of a standard worthy of the name made one inclined to regret that Dr. P'ercy Frankland lind bestowed so large an nmount of lubour in comparing the chemical composition of gas with the nominal illuminating power. If ever $\mathrm{n}$ renlly good standard were obtained, it would be quite impossible to re-calculate Dr. Finalland's results upon that new standard.

Dr. Arsistrosc remarked that the statements of Dr. P. Frankland afforded conclusive evidence on the subject they were discussing. P'rofessor Frankland had on more than one occasion pointed out wlint a very bad article the public were supplied with by the gns companies, and he was glad to sec lis son following in his footstejs and again pointing out the very low quality of the gns supplied to the Metropolis in reference to its illuminating constituents. $\Lambda t$ the same time his observations indiented the direction in which gas manufacturers must proceed in oreler to give the jublic a gas which would satisfy requirements, and be worthy of the present condition of chemical knowledge. He had pointed out, amougst other things, what a grent effect a small amount of benzene lias upon the illuminating power. 'Whey heard on all hands that they were going to recover a very large quantity of benzene and otlier Iyydro. carbons which were at present lost in coking conl, and there was little doubt that if they did recover all that was anticipated tho hydrocalons would become drugs in the market. 'Ilic direction indicated in which they must proceed was perfectly clear, for it was obvious that gas manufacturers might develop their industry to render the gns of sufficient illuminating and henting nower by tho introduction of volatile liyelrocarbons.

Professor SOSTER desired to say a few words with reference to the points which Mr. Hartley and Dr. Frankland had referred to. Mr. Dibdin and himself wero ruther at a disadvantage on the present oceasion; but he lind in his hands a report, which lind been frinted since last November, where the first principles relating to this subject were very fully and fairly discussed, and that discussion, whon published, would enablo thoso who took an intcrest in tho mat ter to better understand the rensons for this now dopar. ture of theirs. The method of obtrining an equality of angle had never, ho thought, been adopted before, and there were some points in connection with it to which he would allurle. With reference to the uso of the dise, light was absorbed, transmitted, and reflected. By so arranging the disc that it makes equal angles with both sources of light, the disposition of the light falling on each side is similar, whatever be the laws with regard to it. 'That wos a fundamental point ; and whatever might be the co-efficient of reflection, \&c., they would be surc of having trustworthy results by arrnoging the dise symmetrically with regred to both the lights compared. But he need not now discuss the matter further, because there was no very ready way of understanding what the co-cflicient of reflection would be. Mr. Hartley had made an observation about the reflection from the disc, but he had failed, npparently, to notice that the incidence of the reflected rays on either side of the disc would be in the same plane, and that any reflected light as supposed would pass in the way shewn [describing by a dingrnm]. Mr. Hartley had, therefore, fallen inther into an error in that matter. Whatever the law of reflection might be, the disc was really illuminnted and viewed under precisely like conditions on either side.

\section{IREPLY}

Dr. Pency Fraskiasd, in reply to the remarks made, snid MIr. Fuster had spoken of the carbonic oxide and nitrogen, and there certainly did sppenr to have been some lenkare from the large proportion of carbonic acid found. On that point, Prof. Pedler, of Calcutta, had told him the previous week that he lind exnmined the Calcutta gas and found it contained, not only 10 per cent. like the Ipswich and Birmingham gas, but 17 per cent. ; so that he supposed the Calcutta gas manufneturers apprecinted the advantages of the introduction of air cven more than it lind been suggested that some of the gns manufucturers in England npprecinted it. (Lnughter.) Mr. Otto Hehner liad regreted that he had unfortunately taken so mueh trouble with these nnalyses, when there was no reliable standard of illuminntimg power; but, of course, he was obliged to be content with what he conld get, and no dumbt if he had lind some of Mr. Dibdin's more relinble standards they would havo been of more value. With regard to Mtr. Caryenter's remints on the temperature of flimes, he lind not investigated them himself, but there were a number of data on the sulject, and as far as they were known they coincided very closely with the results he had obtained. For instnnce, in the ense of the combustible diluents the nmount of hent produced by mnishli-gas was very much in excess of eitlicr carbonic oxide or liydrogen. 'l'le temperaituro was mostly reduced by admixture with carbonic anlyydride; it was next most reduced by nitrogen, and it was lenst reduced by at mospheric nir ; but the reduction in tempernture by the admixtme of nitrogen and atmosplievic nir became inore and more approximite as the proportion of those diluents incrensed. As tho proportions of nitrogen and atmosplicric sir incrensed their illuminating power converged, whilst the rednction in temperature effected by the corbonic anlyydride becamo more than by nitrogen and the ntmosplicric air. 'Thero was a complete accordance, tharefore, between tho flnme temperntures and the illuminating power, so that this matter of the temperature appeared to bo the most important of all.

Mr. Dumus, in reply, snid: With regard to $\mathrm{Mr}$. Hnitley's remnrks on tho high power standard that ho had used such a standard and had found a certain amount of struin upon tho eyesighit from tho increased power of the standard, but be himself lad worked a 
great deal with the 16-candle standard, and though it ! might be that there was a difference between the eyesight of himself and Mr. Hurtley, lie must say that alter a long diny's work with the 16-candlo lamp he felt less exhausted than after a similar day's work with the candles; tho readings were sharper upon the screens, they took less time to observe, and thero was conserjuently much greater relicf for the eyes. On account of the time occupied in trying to balance the position of the disc, when a low power standard was used, one's pyes were tired before the reading could be obtained; but with the 16-candle standard the reading could be taken in a moment; it was as sharp as could be, and the eyes wore rested until the next test had to be taken. He had had a great deal of experience with the 16-candle lamp, and he was bound to say that he did not agree witl the experience of Mr. Hartley. Mr. Heliner spoke as if he lad understood him to say they would actually have another standari of light very shortly, but he was sorry to have given him that impression, as it was, of course, not in his power to eletermine what tho standard should be ; that was a matter for Parliament. No doubt many people desired it, but there was a great deal of difference of opinion on the subject of standards, and until it was settled.which was the best, Parliament would probnbly not do anything. It bad been suggested that two or three should be allowed by the Board of Trade, to bo used if found suitable for the purpose, instead of the present arbitrary rule that only candles should be used. Dr. Frankland hand remarked on the subject of the reflection of the light impinging upon the screen at a greater or less angle. He must confess he liad felt a little puzzled on that point, and it really refunired a great deal of work to elucidate the question thoronghly. Until he had this photometer, the testing of the angular ray's was a matter of very great difficulty and labour, as at every alteration of the angle the distance had to be calculated and mensured, the burner re-ndjusted, the photometer scale re-nrranged, fresl readings taken of the meter, and in fact ench test had to be started de novo. It was tho nuxiety and labour attending all that which induced him to turn lis thoughts to such a design as this radial photometer, and he had shewn that by it it was possible to obtain readings at any angle; only one reading of the meter was required, and two settings of the burner-one for tho rays above and ono for the rays below the horizontal. After the first adjustment only one movement of the burner was required during tho whole of the tests from the vertical above, and to the vertical below; and; conserjuently, the readings taken would bo perfectly relinblo throughout tho wholo series, as the consumption could not jossibly be affected. I Ie must express his sincere thanks to Messrs. If. Sugg and Co., who had made tho instrument for him, for their kind assistnnce, and the caro they had tuken in producing the design.

Profensol Foster resuming, snid with reference to the results of Dr. Jercy Frankland, the figures as to the illuminating value were more important than some other incidental matter; and still he would like to make a few remarks upon tho Inttor. Some years ago it struck him that the fact of the diminution of carbonic oxide, as shewn by tho more recent unalyses, night be dine to the more perfect methods of closing the retorts. He was not prepared to say whether that was tho case or not. Dr. Frnnkland had alluded to tho possibility of air boing introduced throngh tho medium of imperfections in tho rotorts. He (Mtr. Foster) might say that ho thought thore was something undorlying tho system of purification at Birmingham and lpswich, where the proportions of nitrogen were shown to bo so large, which was slightly different from that adopted in the majority of cases. He believed that some gas engineers, after the gas had passed out of the hydraulic main, allowed a certain amount of atmospleric air to bo introluced. It nusist ed the purification. It was difficult to understand the 10 per cent. of nitrogen getting into the gas in any other fashion. How could it be understood as tho result of the temporary closing of tho lid of the retort? He did not know whether they had natent lids at Birmingham or those of the ordinary form. He spoke with the greatest deference on the subject, but there was the 10 per cent. of nitrogen, and those figures were quite exceptional. He certainly believed that it did assist the purification in some instances to admit a certain amount of atmosplheric air. 'The oxygen, as shown in all the analyses had practically disappeared. What became of it? The fact of the ready absorntion of oxygen in gas purification had struck him very much some years ago in the course of some works on which he was then engiged. Sulphide of calcium, as it exists in the ordinary lime purifier, was a very powerful absorbent of oxygen; and there was no clieaper or better way of getting rid of it than by such means. Sulphide of iron wuuld, no doubt, act in a similar way. Really, therefore, the freo oxygen of atmospheric air was never found in the finished gas owing to these circumstances. The report he liad already alluded to would throw some light on tho subject of the illuminating power of hydrocarbons. Mr. Ijibdin and himself had worked it out very carefully for naphthalene, the values for which were expressed in grains per candle power per hour. The results were valutible in themsclves, though he was afraid they had not been working on quite the same line as Dr. Frankland. He liad no cloubt that their figures, imperfect as they might be, would throw some light upon tlie subject. Ono very curious point in counection with the burming of the maphthalene, as was dowe in the nlbocnrbon apparatus, wus that tho illuminating power, due to the naphthalene itself, worked out wouderfully closely for widely different rates of consuniption of naphthalene. The figures all through tho serics were very concorclant, though he regretted that it was nut then in his power to publicly state what they were.

\section{Liberpool Section.}

Chairman : E. K. MIuspratt.

ricc-Chairman : Prof. J. Campbell Brown,.D.Sc. Committec:

\begin{tabular}{|c|c|}
\hline 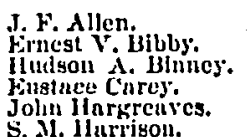 & 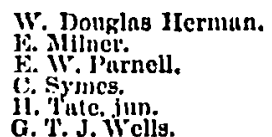 \\
\hline
\end{tabular}

IIon. Scc.: \&. O. Ballard, Qucen's Park, St. IIclens.

Notices of pnpers nnd communications for the meetings to be mnde to Edward Georko Bullurd, Queen's Park, St. Holens.

\section{Uxivelisity Colfege, Ashto: Stheet, Livenrool. Wediestay, $M a t y, t h, 1834$.}

Mr. MUSPRATT IY THE CHAIR.

\section{ON THE ACTION OF NITRATES UPON IRON $A N D$ SULPHIDES IN THE PRESENCE OF CAUS'TIC ALKALI.}

BY G. LUNGE.

Tue Joumal of the Society of Chemical Industry $(1884$, p. 138) contains a paper by Mr. E. W. Parnell, iu 